\title{
THE ANTECEDENTS AND CONSEQUENCES OF COOPERATIVE ARRANGEMENTS INHIBITING THE EMERGENCE OF COOPERATIVE STRATEGIES OF LATVIAN FOREST OWNERS
}

\author{
Andrejs Cirjevskis ${ }^{1}$, Aiga Grasmane ${ }^{2}$ \\ ${ }^{1}$ Riga International School of Economics and Business Administration, Latvia \\ ${ }^{2}$ Forest Owners Association, Latvia \\ cross ${ }^{\text {ref }}$ http://dx.doi.org/10.5755/j01.em.19.1.5992
}

\begin{abstract}
This empirical paper focuses on the specific questions related to market-competition among profit-driven firms versus more cooperative inter-firm arrangements. The share timber produced by the forest owners organizations vary from $31 \%$ in Finland to $75 \%$ of the total share in Norway. However, Latvia is very unique regarding forestry cooperatives; there were no forest owners, cooperatives at all until 2012 year. The aim of the empirical study is to investigate internal and external setting that underpins the commercial viability of strategic choice of cooperative strategies of the Latvian forest owners (FO). We collected primary data by means of interviews and questionnaires answered by experts from the forest sector in Latvia. Our research results illustrate that according to experts' evaluation the group that is the most interested in cooperation is the one that owns 20-50 ha forest and constitutes 26\% of the private forest area; thus it provides a very good potential for forest owners' cooperation. The research findings show that forest owners' cooperatives have opportunities to build their combined competitive advantage through better exploiting their resources and developing new capabilities in order to capture more economic rent. Availability of the EU funds for forestry activities can also be better used by a cooperative than a single FO.
\end{abstract}

The type of the article: Empirical study.

Keywords: cooperative strategy, forest owners' cooperation, commercial viability.

JEL Classification: L14; L22; L73.

\section{Introduction}

Commercially viable strategic choice helps the organization to sustain competitive advantages (Johnson, Whittington \& Scholes, 2011). However, competitive advantages may not always be achieved just by competing. Doz and Hamel (1998) have argued that business strategy has to include cooperative option as well as competitive ones. Nielsen (1988) suggests that the cooperative agreement can be a beneficial cooperative strategy since it can reduce duplication and redundancy. The existence of cooperative strategy does raise a range of questions, not the least of which is whether they make commercially viable strategic choice or not. This empirical paper focuses on the specific questions related to market-competition among profit-driven firms vs. more cooperative inter-firm arrangements. The paper will report on empirical attempts to find an answer to the following question: is it more beneficial to engage in long term cooperative agreement with other firms or is it more advantageous for firms to 'keep their distance' and to interact with each other in a more market-like, transactional way?

\section{The problem}

Swedish private forest owners started to organize themselves in forest owner cooperatives in response to their exposed position on the timber market in the beginning of the last century 
(Lindestav \& Arvidsson, 2012). The share of timber produced by forest owners organizations varies from $31 \%$ in Finland and $75 \%$ of the total share in Norway. However, Latvia is very unique regarding forestry cooperatives - there were no forest owners cooperatives at all until 2012 year. The aim of the study is to investigate the commercial viability of forest owners cooperative strategy in forest industry of Latvia. What we want to know is whether it is commercially viable that Latvian forest owners do not develop their strategies in "splendid isolation', but rather coordinate their strategies to cooperate as a team?

\section{The theoretical background}

Child (1998) was one of the major authors that begun to discuss the commercial viability of strategic choice. He claimed that concept of strategic choice initially originated from the perception that the company's direction was defined by its operational strengths and opportunities. Johnson, Whittington and Scholes (2011) have similar approach to assessment of strategic choice. They, in fact, were the major contributors on the strategy choice viability by applying clear model SFA of examining strategic opportunity through three assessment criteria: suitability, feasibility and acceptability. Suitability links strategic choices to the major factors in an organization's strategic position. Suitability is concerned with assessing which proposed strategies address the key opportunities and constraints an organization faces through an understanding of the strategic position of an organization: it is therefore concerned with the overall rational of a strategy.

Feasibility is about capability. Lack of resources and low levels of competence will make strategy delivery difficult in any organization. Feasibility is concerned with whether a strategy could work in practice. An assessment of feasibility is likely to require two key questions to be addressed: (a) do the resources and competences currently exist to implement a strategy effectively? And (b) if not, can they be obtained?

Acceptability is all about stakeholders. Acceptability is concerned with whether the expected performance outcomes of a proposed strategy meet the expectations of stakeholders. These can be "3Rs": risk, return and stakeholder reactions. It is sensible to use more than one approach in assessing the acceptability of strategy.

Quantitative Strategic Planning Matrix (QSPM) is a strategic management tool that allows strategists to evaluate alternative strategies objectively, based on previous identified external and internal critical success factors and thus to assess the suitability and feasibility of strategic choice (David, 2011). When examining the final part of selecting a strategy in terms of acceptability it is necessary to consider the stakeholders' reaction to each strategic choice. The matrix developed by Mendelow (1991) defines how the stakeholders can impact the company or be impacted by it, and also determines the attitude of the stakeholders towards the company as well as it objectives.

\section{Methods}

The research is carried out under non- contrived settings as a descriptive, cross-sectional study with the minimum researcher interference. Forest owners' of Latvia are serving as the units of the study. The data is collected with the help of interviews and questionnaires, direct observation of the industry development, and eventually, analysis of the publications and studies on private forestry theme. Primary data collections are used by means of interviews and questionnaires answered by experts from forest sector in Latvia. The questionnaire was aimed at finding out which groups of forest owners would be most interested in participation in FOC. The questions included in the questionnaire were both closed and open-ended. The closed-question asks the respondent to make choices among a set of alternatives given by the researchers and open-ended questions allow respondents to answer them in any way they choose (Sekaran \& Bougie, 2010). As for measurement principles, the Questionnaire was designed with the numerical scale depending on the choice provided from 1 to 5 or from 1 to 7 with bipolar attributes at the extremes of the scale (1 means low, 5 means high priority). According to Sekaran and Bougie (2010) sampling is defined as 
the process of selecting the right individuals, objects or events for the research purposes. The criteria that the researchers set as for the choice of respondents was the following: knowledge of timber products market, prices and volumes; familiarity with the ways private forest owners organize their forestry activities; knowledge on the scope of forestry services; knowledge on private forestry structure and its impact in forest industry. Based on the criteria described above the respondents were chosen from the following fields: leaders of the national and local forest owners associations; experts working individually in forestry services business; experts working for companies that provide services to FO and deal with timber sales. Before distributing the questionnaire researchers addressed to selected potential respondents by phone and informed them about the study to be conducted and invited them to respond to the questions in the questionnaire. Then questionnaires have been distributed by email to 20 private forestry experts. The questionnaire was sent out individually to each respondent and the filled forms were received back by email within 2 weeks. This approach appeared to be successful as out of 20 persons addressed 18 responded. Secondary data, such as previous research in private forestry and reports on forest sector's figures as well as other related sources as research articles, reports and industry's reviews were analyzed. Then the semi-structured interviews were planned and conducted. Three persons were interviewed - Executive director of Latvian Federation of Timber Industry, leader of the newly established FOC "Mežsaimnieks", and executive director of State JSC "Latvijas valsts meži”. All interviewees agreed that the information obtained within interviews may be used for the purposes of the current research. Having answered second research question there were two tools applied: Quantitative Strategy Planning Matrix (QSPM) and then Mendelow „Power/Interest"matrix. The QSPM provided a clear comparative platform to evaluate the suitability and feasibility of the strategic choices on cooperative strategy. To analyze the acceptability of the chosen strategy, the Mendelow Matrix has been applied.

\section{Results}

According to Hill and Jones (2008) a fragmented industry is one composed of a large number of small and medium-sized companies. Since there are 150 thousand private forest owners in Latvia and there are no strong local and regional forest owners' organizations it can be concluded that Latvian private forestry is a fragmented industry. Jansons (2010) found that private forestry in Latvia is a very fragmented industry, there are 144069 forest owners with the average forest property size 7.5 ha and about $92 \%$ of all forest owners own less than 20 ha. That is in sharp contrast with Scandinavian countries, where forest sectors are very important sectors of the national economy, the average forest property size is 45 ha in Sweden, 30 ha in Finland, and 50 ha in Norway (Wilhemsson, 2006). We collected primary data by means of interviews and questionnaires answered by experts of forest sector in Latvia. The questionnaire was aimed at finding out which groups of forest owners would be most interested in participation in Forest Owners Cooperatives (FOC) and what the key motivation factors to cooperate are. Our research results illustrate that according to experts' evaluation the group most interested in cooperation would be the ones that own 20-50 ha forest. There is a trend of decreased interest for forest owners with larger forest properties - 100 ha and more. It can be explained by the fact that their forestry resources are sufficient for efficient forest management, timber sales and logistics. However, important conclusion here is that the group of Forest Owner (FO) with $20-50$ ha that constitutes $26 \%$ of the private forest area represent a very perspective owners' group for FOC operations. Then, all respondents agree that there would be price benefit provided by FOC due to potentially bigger volumes of timber's supply and stronger market power. $45 \%$ of the respondents indicate that the price benefit would be minimal about 2.0-5.0 \%\%. Last, but not least, motivating factors to cooperate can be divided into two parts: psychological and practical. According to experts' opinion, the image and role of the FOC leader is one more major important motivator to cooperate. Remembering unsuccessful experience with FOC in the 90ties, nowadays the personality of leader, their integrity, confidentiality and professionalism are critically important to cooperate. FO would 
need to know the leader, recognize and trust him or her.

Quantitative Strategic Planning Matrix provided a summary of the key success factors influencing the viability of cooperative strategy, particularly assessing of suitability and feasibility of the experienced individual competition approach versus perceptiveness of the cooperative strategy as shown in Table 1.

Two strategies of forest owners have been compared and commented by using the QSPM model. It became obviously that a cooperative arrangement approach is more efficient in term of capitalizing of existing external opportunities of private forestry thus proving a suitable and feasible strategic choice that leads to competitive advantages of FO.

Finally, acceptability of cooperative arrangement approach has been analyzed by means of Mendelow matrix. FOC members, forest owners, employees and customers of FOC are the key stakeholders. Almost for all of these stakeholders forest owners' cooperative arrangement approach would commercially viable, except the "middleman" companies. Thus one can be concluded that research added evidences that the FOC is a commercially viable strategy.

Table 1. Quantitative Strategic Planning Matrix (QSPM): suitability and feasibility of strategic choice

\begin{tabular}{|c|c|c|}
\hline Result of external and internal environments & $\begin{array}{c}\text { Individual competitive } \\
\text { scanning }\end{array}$ & $\begin{array}{c}\text { Cooperative } \\
\text { arrangement } \\
\text { approach }\end{array}$ \\
\hline $\begin{array}{c}\text { Internal critical success factors assessment score } \\
\text { (ICFAS) - feasibility }\end{array}$ & 1.88 & 2.53 \\
\hline $\begin{array}{c}\text { External critical success factors assessment score } \\
\text { (ECFAS) - suitability }\end{array}$ & 1.73 & 3.44 \\
\hline Overall strategic factors assessment score (SFAS) & 3.61 & 5.97 \\
\hline
\end{tabular}

Source: adapted by the authors with reference to David (2011)

\section{Discussion}

The aim of forest owners' cooperative strategy is to facilitate more effective management of private forests, more efficient use of timber resources, and better educate of forest owners. The research findings shown that FOCs have opportunities to build their competitive advantage through better exploiting their resources, developing new capabilities by means of better sensing and seizing external market opportunities in order to capture more economic rent (economy of scale, new technologies and access to whole value chain). Two strategies in forest management have been compared by using the QSPM model. The QSPM overall Strategic Factors Assessment Score, $\mathrm{SFAS}=5.97$ for cooperation strategy over the score for individual approach SFAS=3.61 can be explained by the possibilities of a cooperative to capitalize the opportunities in private forestry. Therefore, the cooperative strategy is a suitable strategic choice in terms of capitalizing external opportunities, External Factors Assessment Score (EFAS) is 3.44, feasible in terms of exploiting FO resources and developing capabilities, Internal Factors Assessment Score (IFAS) is 2.53, and acceptable for major stakeholders according to Mendelow matrix analyses result.

Therefore, cooperative arrangement approach is a commercially viable strategic choice. By pooling resources together, appearing economies of scale that will provide advantages to seize and to exploit existing opportunities. Those, in turn, will increase forest management efficiency due to higher market power and reliable supply chain management which is crucially important for all industrial producers. Raising popularity of wood energy will also add opportunities to FOC that doesn't exist in individual competitive approach case. Production of wood energy will requires new technological knowledge, will require higher bargaining powers to negotiate better conditions of contracts with major heating operators and thus will foster an economies of scale that, in turn, will provide more economic rents to FOC as a whole and, consequently, to each FOC member. EU funds for forestry activities development will be also better exploited by a cooperative arrangement approach in comparison with an individual competitive approach. 


\section{References}

Child, J. \& Faulkner, D. (1998). Strategies of Cooperation: Managing Alliances, Networks and Joint Ventures, Oxford. Oxford University Press.

David, F. (2011) Strategic Management Concepts and Cases, $13^{\text {th }}$ ed., 174-203. Prentice Hall.

Doz, Y. \& Hamel, G. (1998). Alliance Advantage: The art of Creating Value through Partnering, 33-169. Harvard Business School Press.

Jansons, J. (2010) Privāto mežu potenciālā devuma Latvijas kokrūpniecībai 2011.-2015.gada novērtējums,132. Latvijas Valsts mežzinātnes institūts ,,SILAVA”,

Johnson, G., Whittington, R. \& Scholes, K. (2011). Exploring Strategy, Text and Cases, $9^{\text {th }}$ ed., 361-389. Pearson Education Limited.

Hill, C. W. L. \& Jones, G. R (2008). Strategic management: an integrated approach, $8^{\text {th }}$ ed. Houghton Mifflin.

Lindestav, G. \& Arvidsson, A. (2012). Member, Owner, Customer, Supplier? The Question of Perspective on Membership and Ownership in a Private Forest Owner Cooperative Global perspective on sustainable forest management. InTech, $5^{\text {th }}$ ch., 75-94.

Mendelow, A. (1991). Stakeholder Mapping. Proceedings of the 2nd International Conference on Information Systems, Plenum Publishers, Cambridge, MA.

Nielsen, R. P. (1988). Cooperative Strategy, Strategic Management Journal, Vol. 9, Issue 5, 475-492. http://dx.doi.org/10.1002/smj.4250090507

Sekaran, U. \& Bougie, R. (2010). Research Methods for Business; Skills Building Approach. $5^{\text {th }}$ ed., Wiley.

Wilhemsson, E. (2006). Forest management planning for private forest owners, Swedish University for Agricultural Sciences, 52-60. 